\title{
Characterization of growth and biochemical composition of sterlet, Acipenser ruthenus L., juveniles from the Dniester population reared in RAS
}

\author{
Oleksyi Khudyi, Ryszard Kolman, Lidia Khuda, Mykhailo Marchenko, Larisa Terteryan
}

Received - 19 September 2014/Accepted - 25 October 2014. Published online: 31 December 2014; $\odot$ Inland Fisheries Institute in Olsztyn, Poland Citation: Khudyi O., Kolman R., Khuda L., Marchenko M., Terteryan L. 2014 - Characterization of growth and biochemical composition of sterlet, Acipenser ruthenus L., juvenile from the Dniester population reared in RAS - Arch. Pol. Fish. 22: 249-256.

\begin{abstract}
A broodstock was created with individuals from the diminishing natural sterlet, Acipenser ruthenus L., population in the upper area of the Dniester basin. Selects and spawners were reared in flow-through tanks with natural thermal regimes. This is the first time artificial reproduction has been performed with this species, followed by incubation and larval rearing. The experimental rearing was conducted in tanks in a recirculating aquaculture system, in which the basic environmental quality parameters were controlled, including water temperature, oxygen saturation, and levels of ammonia and nitrite. During rearing, growth rates and proximate composition of larvae and then juvenile were examined. It was confirmed that during the period of endogenous feeding there was a two-fold decrease in the contents of protein and lipids in the bodies of the larvae. The effects of feeding the sterlet juvenile two different types of commercial feed were compared, and it was confirmed that the feed had a significant impact on sterlet growth rates. The mean daily increase in the body weight of sterlet juvenile fed Skretting feed was 1.91\%, while that in the group fed Aller feed was $0.97 \%$. Additionally, the juvenile from the former group was characterized by higher contents of protein and lipids in both the liver and muscle and the fatty acid profile was more varied.
\end{abstract}

\footnotetext{
O. Khudyi [ $\left.\Xi^{\circ}\right]$, L. Khuda, M. Marchenko, L. Terteryan

Department of Biochemistry and Biotechnology

Chernivtsi National University, Ukraine

e-mail: khudij@email.ua

R. Kolman

Department of Ichthyology

Inland Fisheries Institute in Olsztyn, Poland
}

Keywords: Acipenseridae, intensive rearing, growth rate, biochemical composition

\section{Introduction}

Developing practical methods for the conservation and restoration of stocks of rare fish species threatened with extinction requires performing comprehensive biological studies of individual populations and the conditions in which they occur naturally, the creation of selected broodstocks in aquaculture, and the development of technologies for artificial reproduction and rearing stocking material (Kolman et al. 2011, 2014). Sterlet, Acipenser ruthenus L. is categorized as a fish that is both economically and environmentally valuable. Its meat and roe are particularly highly valued for their nutritional and organoleptic properties. However, current resources of this fish in Ukrainian waters have been greatly diminished (Khudyi and Khuda 2014). Declining abundance of sturgeon populations and, in extreme instances, their extirpation, have been caused by overfishing, constructions to effect river regulation, degraded hydrobiological conditions, and habitat loss (Pikitch et al. 2005). Sterlet is categorized as threatened with 
extinction in Ukraine (Akimov 2009) and throughout its range of occurrence (Gesner et al. 2010).

Sterlet can form potadromous populations in upper river courses, and one such population has survived in the aquatic system of the upper Dniester River (Skilsky et al. 2007). No sturgeon from alien populations have been introduced in this region. Thus, the genetic purity of this autochthonous population remains intact, which renders the sterlet of the upper Dniester particularly valuable ecologically. The abundance of the population is, however, very low. This has prompted work to be undertaken to develop biotechnologies for the artificial reproduction and rearing of stocking material. The program to restore the Baltic Sea population of Atlantic sturgeon, Acipenser oxyrinchus Mitchill, is a positive example of how today's aquaculture technologies can be exploited for conservation measures (Kolman et al. 2014).

Initiating regular restocking with Dniester sterlet juvenile produced in aquaculture is urgent because of the range of anthropogenic and natural factors that could cause the extinction of this fish population in the upper Dniester River. Introducing the Dniester sterlet to aquaculture is not only important for conservation efforts, it is also of economic consequence because of the high commercial value of the species. The factors affecting meat quality and its nutritional value include the contents of protein, lipids, and cholesterol, and the fatty acid profile. This is why much of the focus of the current study was on the effect rearing conditions had on the biochemical composition of the fish. The aim of this study was to determine the impact feeding had on sterlet larvae and juvenile growth rates and on the proximate body composition and fatty acid profile. The assumption was that these results could serve to optimize the nutrition of juvenile sterlet in future

\section{Materials and methods}

The study material comprised sterlet larvae and juvenile of the Dniester population bred using domesticated spawners caught in the wild. Artificial spawning, egg incubation, and initial rearing were conducted at the Ishkhan fishery enterprise on the Cheremosh River in the Chernivtsi Oblast, Ukraine. The juvenile specimens were reared during two experiments performed in tanks in a recirculating aquaculture system at the Department of Biochemistry and Biotechnology, Chernivtsi National University and at the Department of Ichthyology, Inland Fisheries Institute in Olsztyn.

Artificial reproduction, egg incubation, and initial rearing of juvenile were performed in accordance with methods developed for sturgeon (Kolman 2010). The controlled larval rearing period was from hatching until the beginning of intense exogenous feeding. Initially, the larval sterlet were fed Artemia nauplii, and then Perla Larvae pro Activ (Skretting, Norwey) was introduced gradually according to technology developed for sterlet (Kolman et al. 2011). Experimental larval rearing was conducted in tanks with bottom surface areas of $0.5 \mathrm{~m}^{2}$ each at an initial stocking density of 2500 fish $\mathrm{m}^{-2}$. At the beginning of the experiment the water temperature was kept at $16^{\circ} \mathrm{C}$, and was then gradually increased to $18^{\circ} \mathrm{C}$. During larval rearing, the concentrations of oxygen and toxic ammonia and nitrite remained within ranges optimal for sturgeon juvenile (Kolman 2010). During the first experiment, ten sterlet larvae were weighed and measured daily.

The next phase of rearing was performed in recirculating systems at the Department of Biochemistry and Biotechnology, Chernivtsi National University. Three-hundred and twenty individuals were stocked into square tanks with volumes of $1.6 \mathrm{~m}^{3}$ each (200 fish $\mathrm{m}^{-3}$ ). The sterlet were fed during this period with Nutra TT (Skretting). The water temperature ranged from 19 to $22^{\circ} \mathrm{C}$, and the oxygen concentration did not decrease below $70 \%$ saturation. The final stage of the experiment focused on the comparison of the impact different feeds had on the proximate body composition and fatty acid profile. Juvenile aged six months were fed commercial feeds manufactured by Aller Aqua (Poland) and Skretting. According to manufacturer declarations, the Aller Aqua feed contained $45.0 \%$ total protein, $15.0 \%$ lipids, $21.8 \%$ carbohydrates, $6.9 \%$ ash, $3.3 \%$ fiber, $0.2 \%$ sodium, $0.8 \%$ calcium, $1.0 \%$ phosphorus, 10000 IU vitamin 
A, and $1000 \mathrm{IU}$ vitamin $\mathrm{D}_{3}$. The corresponding feed from Skretting had the following composition: $47.0 \%$ total protein, $14 \%$ lipids, $7.5 \%$ ash, $2.6 \%$ fiber, $0.4 \%$ sodium, $1.0 \%$ calcium, $1.1 \%$ phosphorus, and 5000 IU vitamin A.

\section{Biochemical analysis}

Larval sterlet were collected daily for biochemical tests to determine the contents of total protein and lipids $(n=10)$. The specimens used for this were collected for evaluations of growth rate. The comparative biochemical tests were performed on a sample comprising juvenile collected once from both groups $(n=8)$. The mean body weight of the two groups differed with fish fed Aller Aqua feed weighing approximately $130 \mathrm{~g}$, while fish reared on the Skretting feed weighed approximately $160 \mathrm{~g}$.

The contents of total protein in the liver and white muscle homogenate were determined with the Lowry method (Lowry et al. 1951). The lipid fraction was extracted from the sterlet body tissues with the Folch method (Folch et al. 1957). The total lipid content, cholesterol, and fatty acids were determined in the extract. The fatty acids were determined in the laboratory of the Institute of Biochemistry of the Ukrainian National Academy of Sciences using the gas chromatography method and a HRGC 5300 chromatograph with a $3.5 \mathrm{~m}$ glass column filled with Chromosorb W/HP with a $10 \%$ Silar 5CP liquid phase at a programmed temperature range of $140-250^{\circ} \mathrm{C}$ with a $2^{\circ} \mathrm{C}$

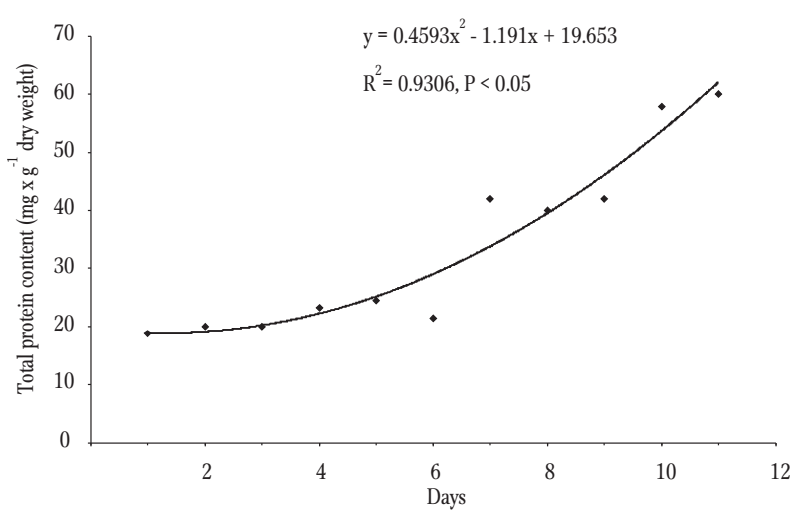

Figure 1. Mean body weight growth of larval Dniester sterlet (A. ruthenus) during initial rearing in RAS tanks. $\min ^{-1}$ gradient. The different fatty acids were identified with standards from Sigma and Serva, and their values were expressed in percentages of the total quantity of fatty acids. The contents of protein, total lipids, and cholesterol were expressed in mg per $1 \mathrm{~g}$ dry tissue weight $\mathrm{mg} \times \mathrm{g}^{-1}$ dry weight

MS Excel was used for statistical processing. Student's t-test was used to determine the significance of differences among groups at a level of significance of $\mathrm{P} \leq 0.05$.

\section{Results and Discussion}

At the end of April when the water temperature increased to $14-15^{\circ} \mathrm{C}$ and following hormonal stimulation, sex products were collected in vivo from sterlet spawners and the eggs were fertilized artificially. The eggs were incubated in Weiss jars. Embryo survival to hatching was approximately $50 \%$.

The specific growth rate of larval sterlet reared at optimal temperatures of $20-22^{\circ} \mathrm{C}$ can range from 5 to $30 \%$ of body weight daily (Gorskii and Yarzhombek 2003). The mean specific growth rate of the larval Dniester sterlet population was $3.8 \mathrm{mg} \mathrm{d}^{-1}$, which was $20.5 \%$ of the mean initial weight. The body weight growth rate was exponential (Fig. 1); however, the mean total body length of sterlet increased during this period by $54.6 \%$ at $23.2 \pm 0.42 \mathrm{~mm}$. Increases in total length at this stage of rearing was linear (Fig. 2). It should be underscored that the water temperature

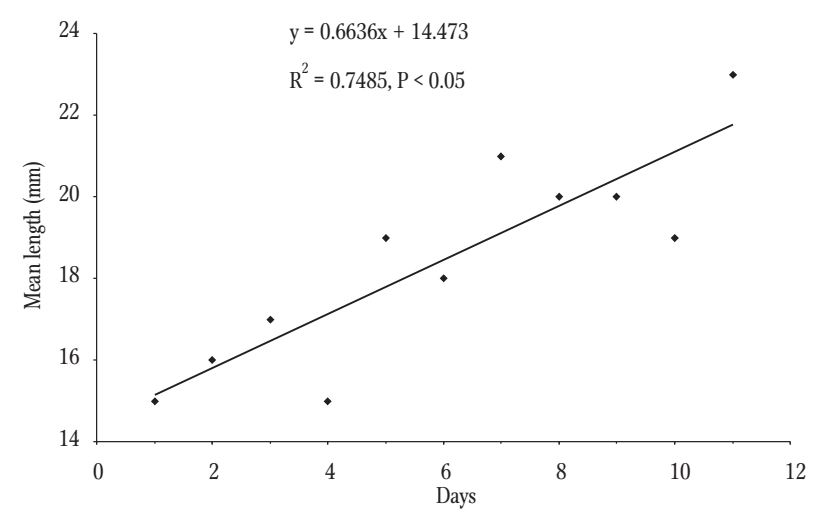

Figure 2. Mean total body length growth of larval Dniester sterlet (A. ruthenus) during initial rearing in RAS tanks. 
in the tanks stocked with larval sterlet was $16-17^{\circ} \mathrm{C}$, which is lower than the optimum for quick growth. Nevertheless, the larval growth rate was fast. During the endogenous feeding phase, the contents of protein (Fig. 3) and total lipids (Fig. 4) decreased nearly two fold. The larvae began exogenous feeding six to seven days after hatching. Changes in feeding cased rapid body weight growth, and increases in the contents of protein and lipids.

The juvenile had reached a mean body weight of $3.46 \pm 0.32 \mathrm{~g}$ by the age of two months. The sterlet were divided into three size groups: the first group comprised $23 \%$ of the total number of fish, and their mean body weight was $1.28 \pm 0.15 \mathrm{~g}$; the second group comprised $45 \%$ of the fish with a mean body weight of $2.94 \pm 0.19 \mathrm{~g}$; the mean body weight of the remaining fish was $5.83 \pm 0.37 \mathrm{~g}$. The maximum and

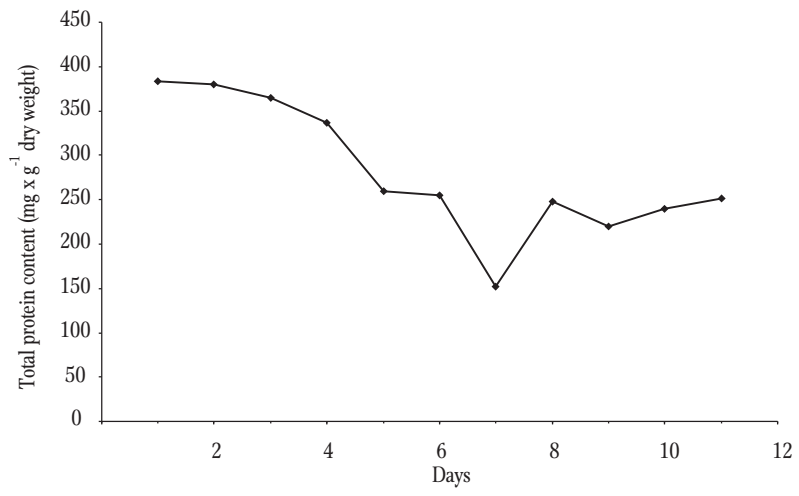

Figure 3. Changes in total protein content in bodies of Dniester sterlet (A. ruthenus) during initial rearing in RAS tanks.

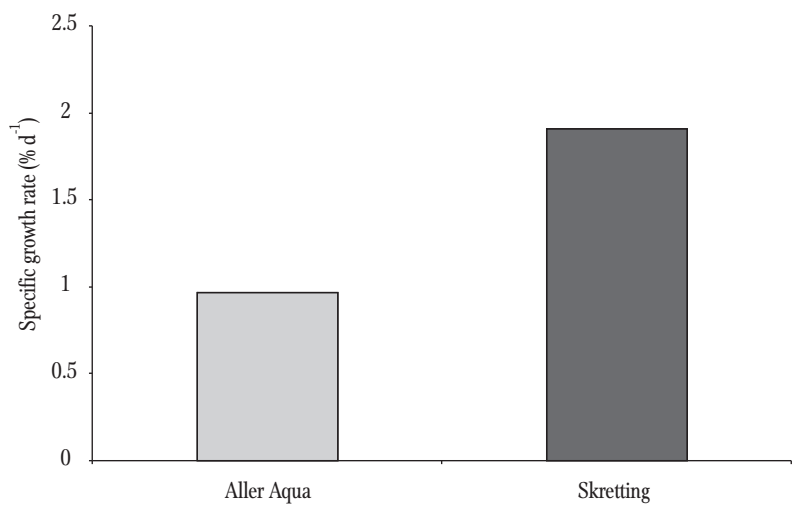

Figure 5. Differences in the specific growth rate of body weight in juvenile starlet (A. ruthenus). minimum juvenile body weights were 8.55 and 1.05 g, respectively.

By the age of four months, the mean body weight of the fish was $22.3 \mathrm{~g}$. In this same period, the mean body weight of the sterlet reared in the tanks at Ishkhan was just $13.5 \mathrm{~g}$; this was probably caused by the low water temperature of $16-17^{\circ} \mathrm{C}$. Data in the literature indicates that sturgeon growth rates decline significantly at water temperatures below $15^{\circ} \mathrm{C}$ (Alimov et al. 2007).

Feeding is a very important element of intensive aquaculture technology. The quality of the feed, its composition, and the technique of its delivery all have a significant impact on fish tissue and organ biochemical indicators (Chipinov et al. 2012). The type of feed had a significant impact on the specific growth rate of the juvenile sterlet (Fig. 5; $\mathrm{P}<0.05$ ).

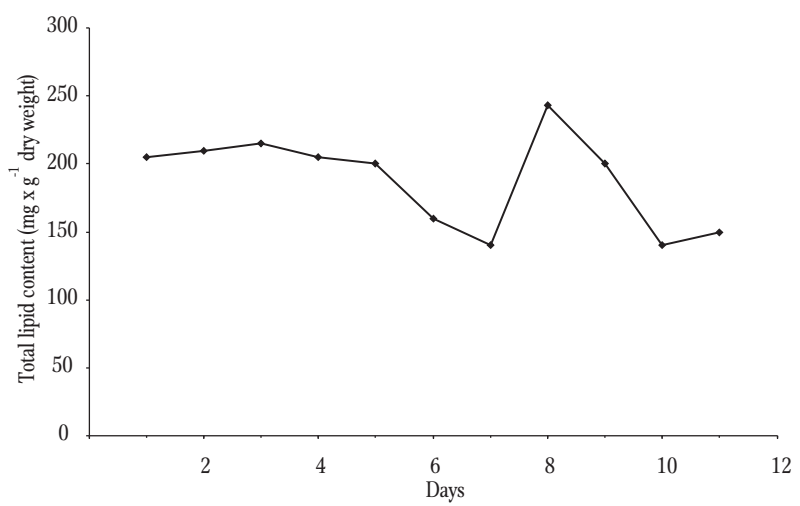

Figure 4. Changes in total lipid content in bodies of Dniester sterlet (A. ruthenus) during initial rearing in RAS tanks.

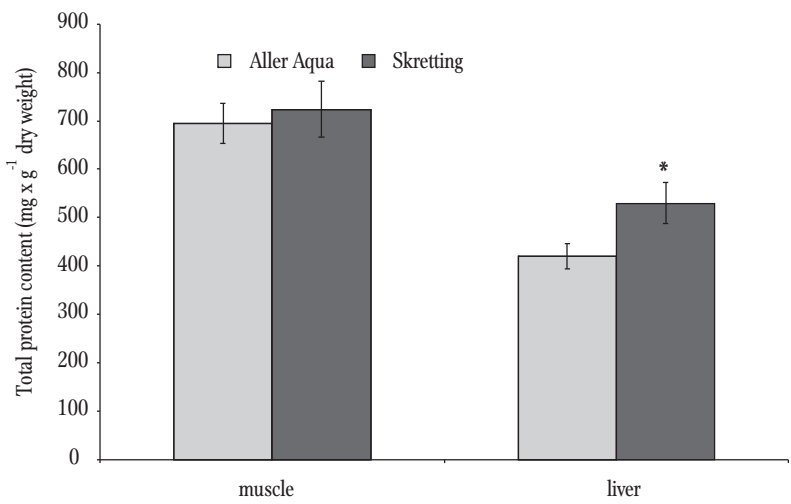

Figure 6. Total protein content in muscles and livers of juvenile sterlet (A. ruthenus). *differences among groups is statistically significant: $\mathrm{P} \leq 0.05$. 


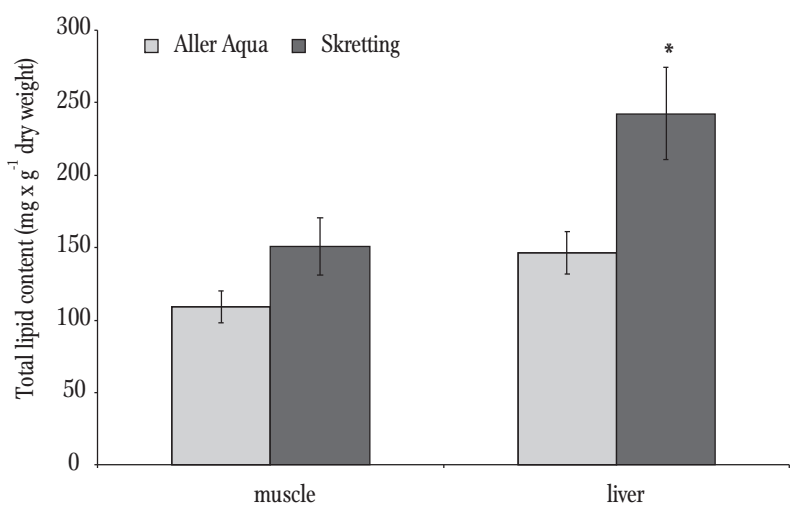

Figure 7. Total lipid content in muscles and livers of sterlet juvenile (A. ruthenus). * differences among groups is statistically significant: $\mathrm{P} \leq 0.05$.

The daily growth rate of sterlet fed the Skretting feed was nearly twice that of the fish fed Aller Aqua feed (1.91 and $0.97 \%$, respectively).

Rearing sterlet under intense aquaculture conditions with artificial feed causes changes in the bodies of these fish in comparison with individuals from natural environments (Kireyev 2011). Accelerated fish growth requires intensified protein synthesis in which the liver plays a special role. The liver is the primary organ for processing large quantities of protein that is then transported to the body, in particular blood serum protein (Yarzhombek 2007). The type of feed had a significant impact on the contents of protein in the livers of the juvenile sterlet (Fig. 6; P < 0.05), but the protein content in muscles of sterlet fed the two feeds compared was similar $(\mathrm{P}>0.05)$. The lipid content and composition in fish from aquaculture differs from that of wild fish. This stems from the composition of the food and various behaviors that demand various expenditures of energy, and these factors lead to increased fat content in the body (Ovissipour and Rasco 2011, Ghomi et al. 2013).

The results of this study confirmed that the type of feed has a statistically significant impact on the liver lipid contents of juvenile sterlet $(\mathrm{P}<0.05)$. The fish fed the Skretting feed had higher liver total lipid contents (Fig. 7). The muscle total lipid content was also higher in the fish fed this feed, but the differences noted were not statistically significant $(\mathrm{P}>$ 0.05). Lipid content was higher in the livers than in the muscles in both groups (Fig. 7).

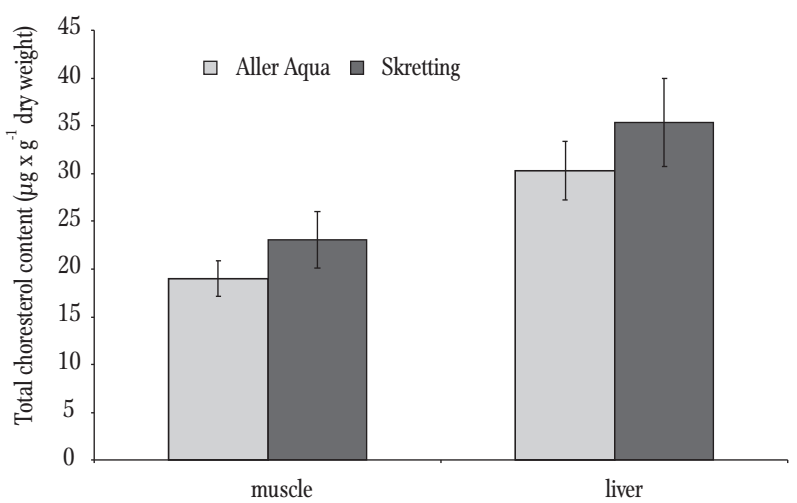

Figure 8. Total cholesterol content in muscles and livers of sterlet juvenile (A. ruthenus).

Cholesterol is one of the essential structural components of cell walls, and it is a precursor of bile acids, steroid hormones, and vitamin $\mathrm{D}_{3}$. Cholesterol is the most commonly occurring sterol in fish tissues. Its content in different tissues and organs fluctuates within a wide range. The highest concentrations are noted in the brain and adrenal glands, a little less in the liver and gastrointestinal mucosa, and the least in the muscles and connective tissue (Kopicová and Vavreinová 2007). The cholesterol occurring in the muscle tissues is mainly the free form and its composition is characterized by high levels of saturated (palmitic acid) and polyunsaturated (oleic and palmitoleic) fatty acids. The greatest quantity of cholesterol is synthesized directly in the livers of fish. However, the speed of sterol synthesis in the liver is substantially slower in fish than in mammals; consequently, most cholesterol is delivered to fish by the food. This is why the cholesterol content in the liver depends on feed quality and feeding intensity. The results of the study indicated slightly lower quantities of cholesterol deposited in the livers and tissues of the fish fed Aller Aqua feed (Fig. 8).

The feeding tests confirmed that the type of feed has a statistically significant impact on the fatty acid profile and content (Table 1). The muscles of juvenile sterlet fed Skretting feed contained 29 fatty acids of which $33 \%$ were saturated (SFA), 39\% monounsaturated (MUFA), and $28 \%$ polyunsaturated (PUFA). The sterlet fed Aller Aqua feed were lacking five fatty acids that were noted in the fish fed 
Table 1

Fatty acid profile (\%) in muscles of juvenile sterlet (A. ruthenus) fed different commercial feeds

\begin{tabular}{|c|c|c|c|}
\hline \multicolumn{2}{|l|}{ Fatty acid } & \multirow{2}{*}{$\begin{array}{l}\text { Aller Aqua } \\
0.30\end{array}$} & \multirow{2}{*}{$\begin{array}{l}\text { Skretting } \\
0.03\end{array}$} \\
\hline Undecanoic & $\mathrm{C} 11: 0$ & & \\
\hline Tridecylic & C13:0 & - & 0.02 \\
\hline Myristic & C14:0 & 3.73 & 5.09 \\
\hline Isomyristic & Ci14:0 & - & 0.02 \\
\hline Pentadecanoic & C15:0 & 0.28 & 0.33 \\
\hline Palmitic & C16:0 & 17.42 & 21.80 \\
\hline Isopalmitic & Ci16:0 & 0.14 & 0.07 \\
\hline Margaric & $\mathrm{C} 17: 0$ & 0.57 & 0.83 \\
\hline Stearic & C18:0 & 2.16 & 1.96 \\
\hline Isostearic & Ci18:0 & 0.24 & 0.37 \\
\hline Arachidic & C20:0 & 1.30 & 1.38 \\
\hline Heneicosylic & C21:0 & 0.31 & 0.30 \\
\hline Behenic & C22:0 & 0.31 & 0.29 \\
\hline$\Sigma$ SFA & & 22.73 & 32.51 \\
\hline Lauricoleic & & 0.06 & 0.08 \\
\hline Myristoleic & C14:1 & 0.09 & 0.22 \\
\hline Palmitoleic & C16:1 & 5.87 & 9.30 \\
\hline Margaroleic & $\mathrm{C} 17: 1$ & 0.53 & 0.74 \\
\hline Oleic & C18:1 & 34.52 & 26.25 \\
\hline Gadoleic & C20:1 & 2.20 & 2.24 \\
\hline$\Sigma$ MUFA & & 43.27 & 38.82 \\
\hline Tetradecanoic & $\mathrm{C} 14: 2$ & - & 0.05 \\
\hline Hexadecanoic & $\mathrm{C} 16: 2 \omega-6$ & - & 0.15 \\
\hline Linoleic & $\mathrm{C} 18: 2 \omega-6$ & 12.31 & 10.99 \\
\hline Linolenic & $\mathrm{C} 18: 3 \omega-3$ & 2.52 & 1.15 \\
\hline Eicosatrienoic & $\mathrm{C} 20: 3 \omega-6$ & 0.19 & 0.10 \\
\hline Arachidonic & C20:4 $\omega-6$ & 0.93 & 0.68 \\
\hline Eicosapentaenoic & $\mathrm{C} 20: 5 \omega-3$ & 6.45 & 7.64 \\
\hline Docosadienoic & $\mathrm{C} 22: 2 \omega-6$ & 0.20 & 0.24 \\
\hline Eicosatrienoic & $\mathrm{C} 22: 3 \omega-3$ & - & 0.11 \\
\hline Docosahexaenoic & $\mathrm{C} 22: 6 \omega-3$ & 6.47 & 6.44 \\
\hline$\Sigma \omega-3$ & & 15.44 & 15.27 \\
\hline$\Sigma \omega-6$ & & 13.63 & 12.13 \\
\hline$\Sigma$ PUFA & & 29.07 & 27.45 \\
\hline
\end{tabular}

the Skretting feed (Table 1). However, the total content of unsaturated fatty acids in the muscles was higher in fish fed the Aller Aqua feed. Thirteen saturated fatty acids were noted in the muscles of juvenile sterlet fed the Skretting feed. The dominant fatty acid was palmitic, while significant amounts of myristic, stearic, and arachidic fatty acids were noted. The shares of the other unsaturated fatty acids did not exceed $1 \%$. It should be underscored that the fatty acid spectrum in the muscles of the fish examined began with undecanoic (C11:0), which was not noted in other studies (Lee et al. 2012, Ljubojevic et al. 2013). 
MUFA comprised approximately $40 \%$ of the fatty acids in the muscles of juvenile sterlet. The greatest fraction of MUFA was of oleic and palmitoleic fatty acids (Table 1). The polyunsaturated fatty acids in sterlet muscles comprised mainly linolenic, eicosapentaenoic, and docosahexaenoic fatty acids.

The results of the present study confirmed that feed had a significant impact on both sterlet growth and body composition. These pilot experiments support the aim of improving feed quality through supplementing missing fatty acids and protein fractions that can have a significant impact on sterlet rearing indicators as well as their condition and the composition of their muscle tissues. This is very important from the standpoint of proposed restoration work and for the development of commercial sterlet production in aquaculture. In the first instance, optimizing feeding will increase the biological value of stocking material, which will result in increased survival in the wild. In the second instance, the economic outcomes of rearing these fish will improve as will the nutritional value of the meat, which will earn the status of a functional food.

Acknowledgements. The study was partly conducted within the framework of the statutory research program of the Inland Fisheries Institute in Olsztyn (No. S025).

Author contributions. O.K., R.K., L.K. and M.M. designed the research; L.K. and L.T. performed the research; O.K., R.K., L.K. and L.T. analyzed the data; O.K. and R.K. wrote the paper.

\section{References}

Akimov I.A. 2009 - Red Book of Ukraine. Animal World Global Consulting, Kiev, 600 p. (in Ukrainian).

Alimov S.I., Yakovleva T.V., Kulyk P.V. 2007 - Sturgeon restoration at the Azov Sea - Fisheries Science of Ukraine 2: 28-33 (in Ukrainian).

Chipinov V.G., Krasil'nikova A.A., Kovalenko M.V. 2012 Comparative evaluation of the application of full-value dry granulate produced in Europe for feeding sturgeon Vesnik AGTU 2: 99-104 (in Russian).
Folch H., Less M., Stanley H.A. 1957 - A simple method for isolation and purification of total lipids from animal tissues - J. Biol. Chem. 226: 497-499.

Ghomi M.R., Nikoo M., Sohrabnezhand M. 2013 - Effect of alive weight on body composition and fatty acid content of farmed beluga sturgeon (Huso huso) - Int. Aquat. Res. 5: 6.

Gesner J., Freyhof J., Kottelat M. 2010 - Acipenser ruthenus The IUCN Red List of Threatened Species. Version 2014.3. <www.iucnredlist.org>. Downloaded on 17 November 2014.

Gorskii S.V., Yarzhombek A.A. 2003 - Textbook materials on fish growth: sturgeons - Moscow, Izdatel'stvo VNIRO, 74 p. (in Russian).

Khudyi O., Khuda L. 2014 - Distribution of sturgeons in the Dniester Basin - In: Actual status and conservation of natural population of sturgeon fish Acipenseridae (Ed.) R. Kolman, Wyd. IRS Olsztyn: 53-59 (in Russian).

Kireyev P.O. 2011 - Comparative analysis of physiological indicators of sterlet reared under natural and aquaculture conditions - Fisheries Science of Ukraine 2: 47-54 (in Russian).

Kolman R. 2010 - Sturgeon: Breeding and rearing. A breeder's guide - Wyd. IRS, Olsztyn, 134 p. (in Polish)

Kolman R., Tretyak A., Zdanowski B., Duda A., Wiszniewski G., Prusinska M. 2011 - Developing effective sterlet stocking material production methods for restoring extirpated populations - In: Conserving genetic resources for restoring populations of valuable fish species, Wyd. DIA, Kiev: 67-69 (in Russian).

Kolman R., Kapusta A., Szczepkowski M., Bogacka-Kapusta E. 2014 - Atlantic-Baltic sturgeon (Acipenser oxyrinchus oxyrinchus Mitchill). Baltic sturgeon restoration program in Poland - Wyd. IRS, Olsztyn 94 p. (in Polish).

Kopicová Z., Vavreinová S. 2007 - Occurrence of squalene and cholesterol in various species of Czech freshwater fish - Czech J. Food Sci. 25: 195-201.

Korchunov A.A., Metallov G.F., Grigor'ev V.A. 2012 Dynamics of the biochemical composition of the bodies and sex products of sterlet (Acipenser ruthenus L.) reared in recirculaing aquaculture systems (RAS) - Rybnoe Khozyajstvo. 1: 136-143 (in Russian).

Lee D.H, Lim S.R., Ra C.S., Kim J.D. 2012 - Effect of dietary garlic extract on whole body amino acid and fatty acid composition, muscle, free amino acid profiles and blood plasma changes in juvenile sterlet sturgeon, Acipenser ruthenus - Asian-Aust. J. Anim. Sci. 10: 1419-1429.

Lowry O.H., Rosebrough N.J., Farr A.L., Randall R.J. 1951 Protein measurement with the folin phenol reagent - J. Biol. Chem. 193: 265-275.

Ljubojevic D., Trbovic D., Lujic J., Bjelic-Cabrilo O., Kostic D., Novakov N., Circovic M. 2013 - Fatty acid composition of fishes from inland waters - Bulg. J. Agric. Sci. Suppl. 1: 62-71. 
Ovissipour M., Rasco B. 2011 - Fatty acid and amino acid profiles of domestic and wild Beluga (Huso huso) Roe and impact on Fertilization Ratio - J. Aquac. Res. Development 2: 113.

Pikitch E.K., Doukakis P., Lauck L., Chakrabarty P., Erickson D.L. 2005 - Status, trends and management of sturgeon and paddlefish fisheries - Fish Fish. 6: 233-265.
Skilsky I.V., Khlus L.M., Cherevatov V.F., Smirnov N.A., Cheredaryk M.I., Khudyi O.I., Meleschuk L.I. 2007 - Red book of Bucovina. Animals Vol. 2, Part 1 - DrukArt, Chernivtsi, 260 p. (in Ukrainian).

Yarzhombek A.A. 2007 - Fish physiology - Kolos, Moscow, 160 p. (in Russian). 